\title{
Synthesis and characterization of a chiral dimeric copper(II) complex: Crystal structure of $\left[\mathrm{Cu}_{2}(\mu-\mathrm{Cl})_{2}(\mathrm{HL})_{2}\right] \cdot \mathrm{H}_{2} \mathrm{O}\left(\mathrm{H}_{2} \mathrm{~L}=\right.$ $S$-(-)-2-[(2-hydroxy-1-phenyl-ethylimino)-methyl]-phenol)
}

\author{
CHULLIKKATTIL P PRADEEP, PANTHAPALLY S ZACHARIAS* and SAMAR K DAS* \\ School of Chemistry, University of Hyderabad, Hyderabad 500 046, India \\ e-mail: skdsc@uohyd.ernet.in
}

\begin{abstract}
Synthesis and characterization of an optically active binuclear dichloro-bridged copper(II) complex $\left[\mathrm{Cu}_{2}(\mu-\mathrm{Cl})_{2}(\mathrm{HL})_{2}\right] \cdot \mathrm{H}_{2} \mathrm{O} \mathbf{1}\left(\mathrm{H}_{2} \mathrm{~L}=S\right.$ - $(-)-2-[(2-$ hydroxy-1-phenyl-ethylimino $)$-methyl]-phenol $)$ of a Schiff-base derived from salicylaldehyde and $(S)-(+)-2$-phenylglycinol are described. Compound 1 crystallizes in the orthorhombic chiral $P 2_{1} 2_{1} 2_{1}$ space group with $Z=4, a=10 \cdot 21(2), b=11 \cdot 574(3)$, $c=25 \cdot 364(9)$. Each copper shows square pyramidal geometry with $\mathrm{O}_{2} \mathrm{NCl}_{2}$ coordination and the $\mathrm{Cu}_{2} \mathrm{Cl}_{2}$ core geometry adopts a butterfly shape. Crystals of $\mathbf{1}$ were further characterized by elemental analysis, IR, UV-visible and EPR spectroscopy and circular dichroism (CD) studies.
\end{abstract}

Keywords. Dinuclear copper(II) complex; crystal structure; chiral properties.

\section{Introduction}

Binuclear complexes of copper have received much attention because of their relevance to the type 3 copper found in multicopper-containing proteins such as the tyrosinase, hemocyanins and copper oxidases. ${ }^{1}$ There are many reports on modelling the copper dinuclear active sites of these proteins. ${ }^{2}$ Many of these proteins are believed to contain the copper ions in dissymmetric ligand arrangements and therefore modelling the structural aspects of this dissymmetric ligand environment around copper is currently of great interest. ${ }^{3-6}$ Chiral dinuclear complexes of copper(II) have received special attention because of their importance in molecular self-recognition. ${ }^{5,6}$ In our continued efforts to synthesize complexes of optically active Schiff-bases, ${ }^{7}$ we have prepared a dichloro-bridged dinuclear copper(II) complex $\left[\mathrm{Cu}_{2}\right.$ $\left.(\mu-\mathrm{Cl})_{2}(\mathrm{HL})_{2}\right] \cdot \mathrm{H}_{2} \mathrm{O} \quad \mathbf{1}\left(\mathrm{H}_{2} \mathrm{~L}=S\right.$-(-)-2-[(2-hydroxy-1phenyl-ethylimino)-methyl]-phenol) of a chiral Schiffbase prepared from salicylaldehyde and (S)-(+)-2phenylglycinol. We report here the synthesis, structural characterization and properties of the chiral complex 1 .

Dedicated to the memory of the late Professor Bhaskar G Maiya *For correspondence

\section{Experimental}

\subsection{Physical measurements}

Microanalytical $(\mathrm{C}, \mathrm{H}, \mathrm{N})$ data were obtained with a Flash EA 1112 Series CHNS analyser. A Shimadzu 3101-PC UV/Vis/NIR spectrophotometer was used to record the electronic spectra. Infrared spectra were collected by using $\mathrm{KBr}$ pellets on a Jasco-5300 FT-IR spectrophotometer. The $\mathrm{CD}$ spectra were measured with a Jasco J-810 spectropolarimeter. EPR spectra were recorded on a Jeol JES-FA200 spectrometer.

\subsection{Synthesis of the enantiopure ligand $\mathrm{H}_{2} \mathrm{~L}$}

Synthesis and characterization of the ligand $\mathrm{H}_{2} \mathrm{~L}$ ( $S$ (-)-2-[(2-hydroxy-1-phenyl-ethylimino)-methyl]-phenol) have been reported earlier. ${ }^{7}$

\subsection{Synthesis of $\mathbf{1}$}

$\mathrm{CuCl}_{2} \cdot 2 \mathrm{H}_{2} \mathrm{O}(0 \cdot 179 \mathrm{~g}, 1 \mathrm{mmol})$ was added to a methanolic solution of the ligand $\mathrm{H}_{2} \mathrm{~L}(0.241 \mathrm{~g}, 1 \mathrm{mmol})$. The mixture was stirred at room temperature in air overnight. The resultant green solution was evaporated to dryness using a rotavapor and vacuum pump. The green coloured solid thus obtained was recrystallized from ethanol. Yield was $163 \mathrm{mg}$ (47\%).

Analysis: Calc. for $\mathrm{C}_{30} \mathrm{H}_{30} \mathrm{~N}_{2} \mathrm{O}_{5} \mathrm{Cl}_{2} \mathrm{Cu}_{2}$ : C, 51.73; $\mathrm{H}, 4.34 ; \mathrm{N}, 4 \cdot 02 \%$. Found C, 53.26; H, 4.2; N, 4.09\%. 
UV/Vis $(\mathrm{MeOH}): \lambda_{\max }, \mathrm{nm}\left(\stackrel{\circ}{a}, \mathrm{M}^{-1} \mathrm{~cm}^{-1}\right): 682 \cdot 00$ (172), 372.00 (9567), 271.00 (23649), 223 (44250).

IR (KBr): 1626.14, 1541.26, 1467.96, 1442.88, $1294 \cdot 35,1199 \cdot 83,1149 \cdot 68,1126 \cdot 53,1068 \cdot 66,1006 \cdot 93$, $945 \cdot 20,896 \cdot 98,761 \cdot 95,700 \cdot 22,590 \cdot 27,528 \cdot 54$, $430 \cdot 16 \mathrm{~cm}^{-1}$.

\section{$2.4 X$-ray crystallography}

Single crystals of the complex $\mathbf{1}$ were grown by slow evaporation of an ethanol solution. Unit cell determination and data collection were performed on an Enraf-Nonius Mach3 single crystal diffractometer using graphite monochromated $\mathrm{Mo}-\mathrm{K}_{\alpha}$ radiation $(\lambda=0.71013 \AA)$. An empirical absoption correction was applied to the data, based on the $\psi$-scans of three reflections. ${ }^{8}$ Programs of WinGX ${ }^{9}$ were used for data reduction and absorption correction. The structure was solved by direct methods and refined on $F^{2}$ by full-matrix least squares procedures using SHELX97 programs. ${ }^{10}$ The absolute configuration for the compound molecule was successfully determined by refining the Flack parameter $(0.034(19)) .{ }^{11}$ Additional details of the data collection parameters and refinement are collected in table 1. CCDC-255828 contains the supplementary crystallographic data for complex 1. This can be obtained free of charge on application to CCDC, 12 Union Road, Cambridge CB21EZ, UK (Fax: (+44)1223-336-033; email: deposit@ccdc.cam.ac.uk).

\section{Results and discussion}

The dinuclear copper complex $\mathbf{1}$ is synthesized in moderate yield by mixing equimolecular amounts of $\mathrm{CuCl}_{2} \cdot 2 \mathrm{H}_{2} \mathrm{O}$ and the ligand $\mathrm{H}_{2} \mathrm{~L}$ in a methanolic solution as shown in the following equation:

$$
\begin{aligned}
2 \mathrm{CuCl}_{2} \cdot 2 \mathrm{H}_{2} \mathrm{O} & +2 \mathrm{H}_{2} \mathrm{~L} \rightarrow\left[(\mathrm{HL}) \mathrm{Cu}(\mu-\mathrm{Cl})_{2} \mathrm{Cu}(\mathrm{HL})\right] \\
& +2 \mathrm{HCl}+4 \mathrm{H}_{2} \mathrm{O} .
\end{aligned}
$$

Single crystals of $\mathbf{1}$ are obtained by recrystallization from ethanol, and crystal structure of the complex 1 has been determined by means of single-crystal X-ray diffraction analysis. Table 2 displays its selected bond distances and angles.

The complex crystallizes in a noncentrosymmetric orthorhombic chiral space group $P 2_{1} 2_{1} 2_{1}$ with four molecules per unit cell. The unit cell also contains four water molecules. The thermal ellipsoid plot for the molecular structure of complex $\mathbf{1}$ is presented in figure 1. Each complex is hydrogen-bonded to one water molecule. The structure consists of dimeric $\mathrm{Cu}_{2} \mathrm{Cl}_{2}(\mathrm{HL})_{2}$ units with a central non-planar $\mathrm{Cu}_{2} \mathrm{Cl}_{2}$ ring. The dihedral angle between the planes defined by $\mathrm{Cu} 1, \mathrm{Cl} 1, \mathrm{Cl} 2$ and $\mathrm{Cu} 2, \mathrm{Cl} 1, \mathrm{Cl} 2$ is $25.8^{\circ}$. Each $\mathrm{Cu}$ atom is penta-coordinated with distorted square-pyramidal geometry. Generally, the dichloro-bridged squarepyramidal copper complexes with square pyramid geometry exhibit three different geometries with regard to the relative arrangement of square pyramids, viz. perpendicular bases (type I), parallel bases (type II) and coplanar bases (type III). ${ }^{12}$ The asymmetric arrangement of the $\mathrm{Cu}_{2} \mathrm{Cl}_{2}$ moiety in complex 1 belongs to type II. In the crystal structure, two pentacoordinated copper complexes with square-pyramidal geometry share a base to apex edge so that the $\mathrm{Cl}$ atom, situated at the vertex of one base, becomes the apex of the other square pyramid and vice versa for the other Cl-bridging ligand (figure 2). Analysis of the shape-determining angles using the approach of Reedijk et $\mathrm{l}^{13}$ yields a $\hat{o}$ value of $0 \cdot 1528$ for $\mathrm{Cu} 1$ and 0.2878 for $\mathrm{Cu} 2$, indicating that the distortion is more towards square pyramidal. There is evidence for the involvement of imidazole and phenoxide ligands around the copper centres in oxyhemocyanins in square-pyramidal geometry. ${ }^{14}$ Within the asymmetric $\mathrm{Cu}(\mu-\mathrm{Cl})_{2} \mathrm{Cu}$ core, the $\mathrm{Cu}-\mathrm{Cu}$ distance is $3 \cdot 381 \AA$, the two shorter $\mathrm{Cu}(1)-\mathrm{Cl}(1)$ and $\mathrm{Cu}(2)-$ $\mathrm{Cl}(2)$ distances are 2.245(4) and 2.267(2) $\AA$, the two longer $\mathrm{Cu}(1)-\mathrm{Cl}(2)$ and $\mathrm{Cu}(2)-\mathrm{Cl}(2)$ distances are 2.8802(17) and 2.6874(15) $\AA$; and $\mathrm{Cu}(1)-\mathrm{Cl}(1)-\mathrm{Cu}(2)$ and $\mathrm{Cu}(1)-\mathrm{Cl}(2)-\mathrm{Cu}(2)$ angles are $86.03(5)$ and

\begin{tabular}{|c|c|}
\hline Empirical formula & $\mathrm{C}_{30} \mathrm{H}_{30} \mathrm{Cl}_{2} \mathrm{Cu}_{2} \mathrm{~N}_{2} \mathrm{O}_{5}$ \\
\hline Formula weight & $696 \cdot 54$ \\
\hline Crystal system & Orthorhombic \\
\hline Space group & $P 2_{1} 2_{1} 2_{1}$ \\
\hline$\lambda(\AA)$ & 0.71073 \\
\hline$a(\AA)$ & $10 \cdot 21(2)$ \\
\hline$b(\AA)$ & $11 \cdot 574(3)$ \\
\hline$c(\AA)$ & $25 \cdot 364(9)$ \\
\hline$U\left(\AA^{3}\right)$ & $2998(6)$ \\
\hline$Z$ & 4 \\
\hline$\grave{i}\left(\mathrm{~mm}^{-1}\right)$ & 1.638 \\
\hline$T\left({ }^{\circ} \mathrm{C}\right)$ & 25 \\
\hline Independent reflections & 3856 \\
\hline$R_{\text {int }}$ & $0 \cdot 0000$ \\
\hline Obs reflections $[F>4 o ́(F)]$ & 2882 \\
\hline$R_{1}{ }^{\mathrm{a}}[F>4 o ́(F)]$ & $0 \cdot 0362$ \\
\hline$w R_{2}^{\mathrm{b}}$ & $0 \cdot 0707$ \\
\hline
\end{tabular}

Table 1. Crystallographic data for $\mathbf{1}$ 
$81 \cdot 16(6)^{\circ}$ respectively. In this context, it is worth mentioning that a number of dichloro-bridged dicopper complexes have been reported in the literature and many of these are structurally characterized. ${ }^{15}$

The compound shows high intensity IR bands around $1626 \mathrm{~cm}^{-1}$, typical of conjugated $\mathrm{C}=\mathrm{N}$ stretching. The carbon-oxygen stretch at $1541 \mathrm{~cm}^{-2}$ indicates a nonbridging phenolate ligand.

The absorption spectrum of $\mathbf{1}$ in $\mathrm{MeOH}$ is shown in figure 3. A broad $d-d$ band (dashed line, figure 3) is obtained in the visible region (at $682 \mathrm{~nm}$ ), a feature characteristic of many $\mathrm{Cu}(\mathrm{II})$ systems. The band at

Table 2. Selected bond lengths $[\AA]$ and angles $\left[{ }^{\circ}\right]$ for $\mathbf{1}$.

\begin{tabular}{lc}
\hline $\mathrm{Cu}(1)-\mathrm{O}(1)$ & $1 \cdot 901(4)$ \\
$\mathrm{Cu}(1)-\mathrm{N}(1)$ & $1 \cdot 949(5)$ \\
$\mathrm{Cu}(1)-\mathrm{O}(2)$ & $1 \cdot 996(3)$ \\
$\mathrm{Cu}(1)-\mathrm{Cl}(1)$ & $2 \cdot 245(4)$ \\
$\mathrm{Cu}(1)-\mathrm{Cl}(2)$ & $2 \cdot 8802(17)$ \\
$\mathrm{Cu}(2)-\mathrm{O}(3)$ & $1 \cdot 895(4)$ \\
$\mathrm{Cu}(2)-\mathrm{N}(2)$ & $1 \cdot 933(4)$ \\
$\mathrm{Cu}(2)-\mathrm{O}(4)$ & $2 \cdot 037(4)$ \\
$\mathrm{Cu}(2)-\mathrm{Cl}(2)$ & $2 \cdot 267(2)$ \\
$\mathrm{Cu}(2)-\mathrm{Cl}(1)$ & $2 \cdot 6874(15)$ \\
$\mathrm{N}(2)-\mathrm{C}(22)$ & $1 \cdot 291(6)$ \\
$\mathrm{N}(2)-\mathrm{C}(23)$ & $1 \cdot 496(6)$ \\
$\mathrm{N}(1)-\mathrm{C}(7)$ & $1 \cdot 281(7)$ \\
& \\
$\mathrm{O}(1)-\mathrm{Cu}(1)-\mathrm{N}(1)$ & $93 \cdot 19(19)$ \\
$\mathrm{O}(1)-\mathrm{Cu}(1)-\mathrm{O}(2)$ & $174 \cdot 81(16)$ \\
$\mathrm{N}(1)-\mathrm{Cu}(1)-\mathrm{O}(2)$ & $82 \cdot 94(18)$ \\
$\mathrm{O}(1)-\mathrm{Cu}(1)-\mathrm{Cl}(1)$ & $92 \cdot 29(15)$ \\
$\mathrm{N}(1)-\mathrm{Cu}(1)-\mathrm{Cl}(1)$ & $165 \cdot 64(12)$ \\
$\mathrm{O}(2)-\mathrm{Cu}(1)-\mathrm{Cl}(1)$ & $92 \cdot 28(14)$ \\
$\mathrm{O}(3)-\mathrm{Cu}(2)-\mathrm{N}(2)$ & $94 \cdot 74(19)$ \\
$\mathrm{O}(3)-\mathrm{Cu}(2)-\mathrm{O}(4)$ & $176 \cdot 70(15)$ \\
$\mathrm{N}(2)-\mathrm{Cu}(2)-\mathrm{O}(4)$ & $82 \cdot 64(18)$ \\
$\mathrm{O}(3)-\mathrm{Cu}(2)-\mathrm{Cl}(2)$ & $93 \cdot 65(16)$ \\
$\mathrm{N}(2)-\mathrm{Cu}(2)-\mathrm{Cl}(2)$ & $159 \cdot 43(12)$ \\
$\mathrm{O}(4)-\mathrm{Cu}(2)-\mathrm{Cl}(2)$ & $88 \cdot 18(15)$ \\
$\mathrm{O}(3)-\mathrm{Cu}(2)-\mathrm{Cl}(1)$ & $93 \cdot 80(12)$ \\
$\mathrm{N}(2)-\mathrm{Cu}(2)-\mathrm{Cl}(1)$ & $102 \cdot 03(12)$ \\
$\mathrm{O}(4)-\mathrm{Cu}(2)-\mathrm{Cl}(1)$ & $88 \cdot 73(11)$ \\
$\mathrm{Cl}(2)-\mathrm{Cu}(2)-\mathrm{Cl}(1)$ & $96 \cdot 10(5)$ \\
$\mathrm{Cu}(1)-\mathrm{Cl}(1)-\mathrm{Cu}(2)$ & $86 \cdot 03(5)$ \\
$\mathrm{Cu}(2)-\mathrm{Cl}(2)-\mathrm{Cu}(1)$ & $81 \cdot 16(6)$ \\
$\mathrm{C}(22)-\mathrm{N}(2)-\mathrm{C}(23)$ & $120 \cdot 9(4)$ \\
$\mathrm{C}(22)-\mathrm{N}(2)-\mathrm{Cu}(2)$ & $124 \cdot 9(4)$ \\
$\mathrm{C}(23)-\mathrm{N}(2)-\mathrm{Cu}(2)$ & $113 \cdot 9(3)$ \\
$\mathrm{C}(30)-\mathrm{O}(4)-\mathrm{Cu}(2)$ & $108 \cdot 2(3)$ \\
$\mathrm{C}(7)-\mathrm{N}(1)-\mathrm{C}(8)$ & $120 \cdot 2(4)$ \\
$\mathrm{C}(7)-\mathrm{N}(1)-\mathrm{Cu}(1)$ & $125 \cdot 6(3)$ \\
$\mathrm{C}(8)-\mathrm{N}(1)-\mathrm{Cu}(1)$ & \\
$\mathrm{C}(16)-\mathrm{O}(3)-\mathrm{Cu}(2)$ & $\mathrm{C}(3)$ \\
$\mathrm{C}(1)-\mathrm{O}(1)-\mathrm{Cu}(1)$ & \\
$\mathrm{C}(15)-\mathrm{O}(2)-\mathrm{Cu}(1)$ & \\
& \\
& \\
&
\end{tabular}

$372 \mathrm{~nm}$ might be assigned to a metal-to-ligand chargetransfer (MLCT) transition. The sharp peaks in the 200-290 nm range of the electronic spectrum are due

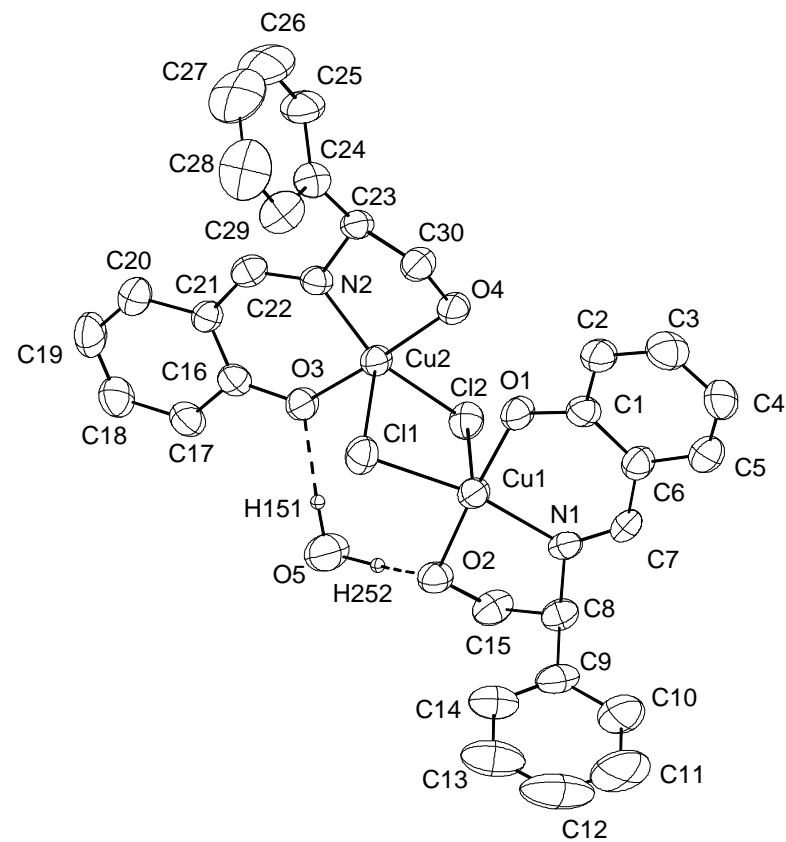

Figure 1. Thermal ellipsoid plot (50\% probability) and atom labelling for 1. Hydrogen atoms are omitted for clarity except water hydrogens. The hydrogen bonding parameters for the solvent water are O5-H151…O3 0.99

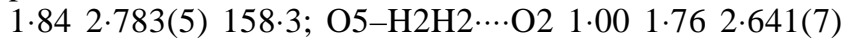
$143 \cdot 4$.

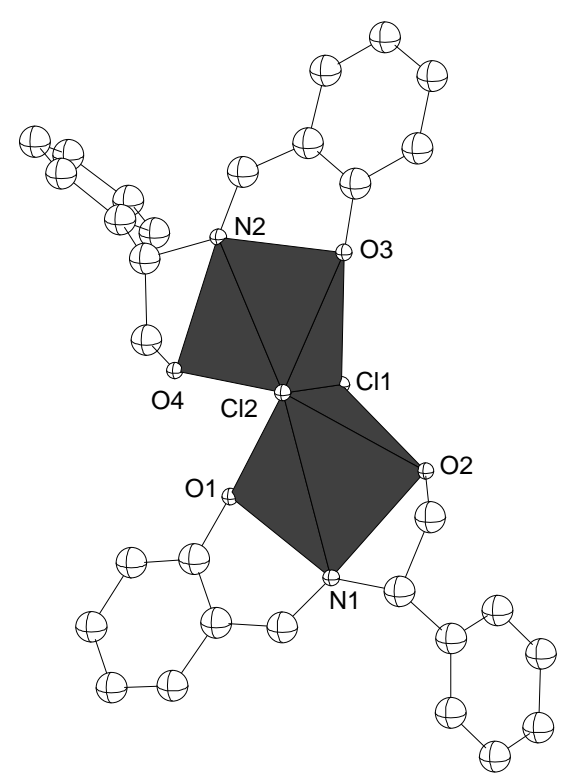

Figure 2. The relative arrangement of square pyramid moieties around the copper atoms showing base-to-apex edge sharing. 


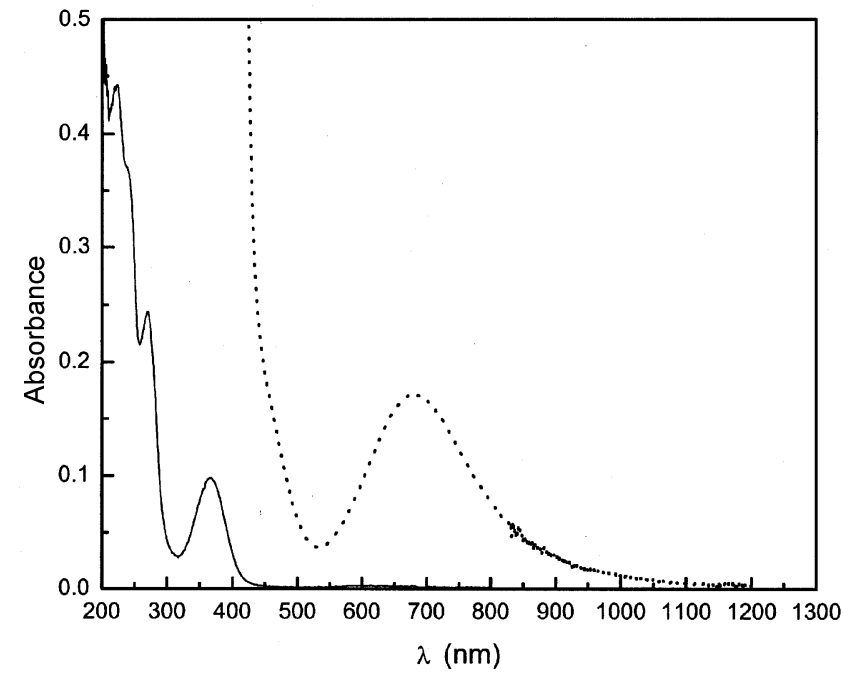

Figure 3. Electronic spectra of $\mathbf{1}$ in methanol solution (solid line: $1 \times 10^{-5} \mathrm{M}$ and dashed line: $1 \times 10^{-3} \mathrm{M}$ ).

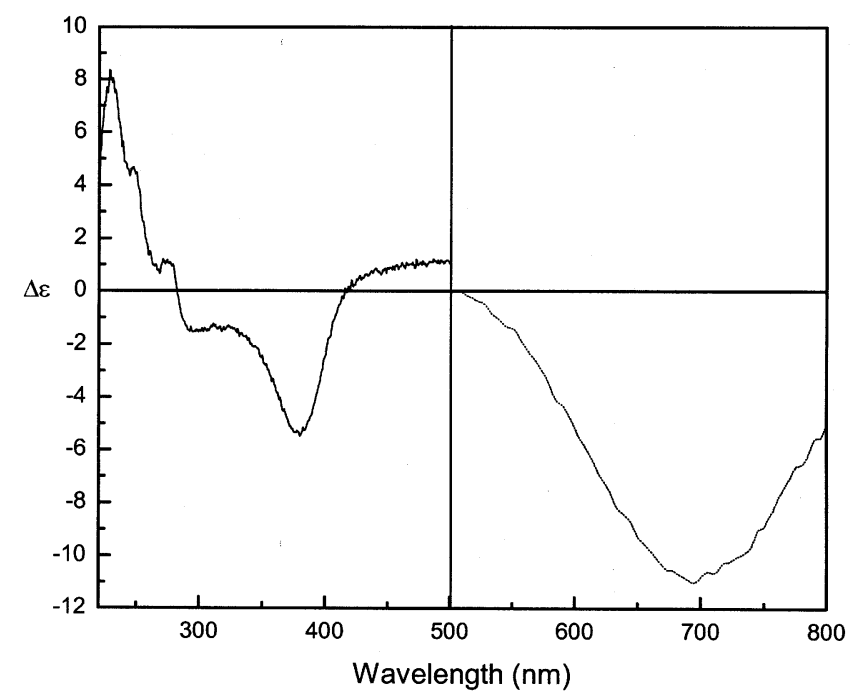

Figure 4. Circular dichroism spectra of $\mathbf{1}$ in methanol solution (solid line: $1 \times 10^{-5} \mathrm{M}$ and dashed line: $1 \times 10^{-3} \mathrm{M}$ ).

to intraligand charge transfer (ILCT) transitions, judging from their molar extinction coefficient values.

Optical activity of the dimeric copper complex 1 is induced by the enantiopure ligand $\mathrm{H}_{2} \mathrm{~L}(=S-(-)-2-$ [(2-hydroxy-1-phenyl-ethylimino)-methyl]-phenol).

The circular dichroism (CD) spectrum of the ligand, $\mathrm{H}_{2} \mathrm{~L}$, has been reported earlier ${ }^{7}$ and shows a negative band around $315 \mathrm{~nm}$. The CD spectrum of complex 1, as expected, exhibits negative bands at $372 \mathrm{~nm}$ (MLCT), $682 \mathrm{~nm}(d-d)$ and in the UV region (ILCT) as shown in figure 4 .

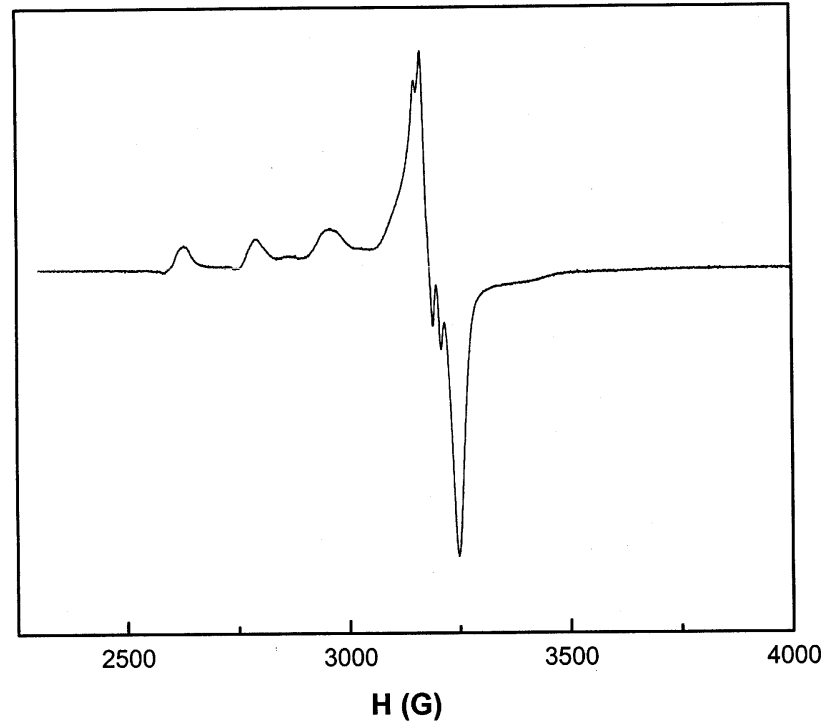

Figure 5. EPR spectrum of $\mathbf{1}$ in methanol solution at liquid nitrogen temperature.

EPR spectrum of $\mathbf{1}$ in frozen methanol is displayed in figure 5. This is typical of a monomeric tetragonal $\mathrm{Cu}(\mathrm{II})$ complex with a $d_{x^{2}-y^{2}}$ ground-state doublet. This experiment suggests that the bis( $\mu$-halo)-bridged structure, $\left[(\mathrm{HL}) \mathrm{Cu}(\mu-\mathrm{Cl})_{2} \mathrm{Cu}(\mathrm{HL})\right]$, is dissociated in solution presumably due to additional coordination by the solvent molecules. Similar behaviour has been observed for the other chloro-bridged dimeric copper complexes. ${ }^{16}$ This observation is consistent with the fact that chloride bridges are weak in the crystalline state of $\mathbf{1}$ in terms of $\mathrm{Cu}-\mathrm{Cl}$ distances (2.8802(16), $2 \cdot 6872(15))$. Thus the copper dimer complex 1 is readily dissociable in solution. The $g$ values $\left(g_{\|}=\right.$ $\left.2 \cdot 288, g_{\perp}=2 \cdot 063, A_{\|}=164 \mathrm{G}\right)$ are comparable with those of other dinuclear $\mathrm{Cu}(\mathrm{II})$ complexes. ${ }^{16,17}$ Interestingly, the nitrogen superhyperfine splitting is observed in the $g_{\perp}$ region $\left(A_{\perp}{ }^{\mathrm{N}}=16.5 \mathrm{G}\right)$ as shown in figure 5 .

\section{Conclusions}

Copper-containing proteins are shown to contain the copper ions in dissymmetric ligand arrangements. We have described, for the first time, a chiral dichlorobridged dimeric copper(II) complex. Both copper centres adopt square-pyramidal geometry, which is also found in copper-containing oxyhemocyanins. The chirality of the complex is supported by circular dichroism studies. 


\section{Acknowledgements}

We acknowledge the Department of Science and Technology (DST), Government of India, for financial support. X-ray crystallographic data were obtained from the National Single Crystal Diffractometer Facility at the School of Chemistry, University of Hyderabad. We are grateful to the University Grants Commission (UGC), New Delhi, for infrastructure facility at the University of Hyderabad, under UPE grant. CPP thanks the UGC, Government of India, for a fellowship.

\section{References}

1. Ochiai E I 1977 Bioinorganic chemistry; An introduction (Boston, MA: Allyn and Bacon) ch. 9

2. Sorrell T N 1989 Tetrahedron 453

3. Telfer S G, Sato T, Harada T, Kuroda R, Lefebvre J and Leznoff D B 2004 Inorg. Chem. 436168

4. Deschamps P, Kulkarni P P and Sarkar B 2003 Inorg. Chem. 42 7366; Adams H, Fenton D E, McHugh P E and Potter T J 2002 Inorg. Chim. Acta 331 117; Amudha P, Akilan P and Kandaswamy M 2000 Polyhedron 19 1769; Amudha P, Thirumavalavan $\mathrm{M}$ and Kandaswamy M 1999 Polyhedron 181363
5. Rowland J M, Olmstead M M and Mascharak P K 2002 Inorg. Chem. 411545

6. Masood M A, Enemark E J and Stack T D P 1998 Angew. Chem., Int. Ed. 37928

7. Pradeep C P, Htwe T, Zacharias P S and Das S K 2004 New. J. Chem. 28735

8. North A C T, Philips D C and Mathews F S 1968 Acta Crystallogr. A24 351

9. Farrugia L J 1999 J. Appl. Crystallogr. 32837

10. Sheldrick G M 1997 SHELX-97, Structure Determination Software, University of Göttingen, Göttingen, Germany

11. Flack H D 1983 Acta Crystallogr. A39 876

12. Rodríguez M, Llobet A, Corbella M, Martell A E and Reibenspies J 1999 Inorg. Chem. 382328

13. Addison A W, Rao T N, Reedijk J, Rijn J V and Verschoor G C 1984 J. Chem. Soc., Dalton Trans. 1349

14. Beinert H 1980 Coord. Chem. Rev. 33 55; Amundson A R, Whelan J and Bosnick B $1977 \mathrm{~J}$. Am. Chem. Soc. 996730

15. Kapoor P, Pathak A, Kapoor R, Venugopalan P, Corbella M, Rodríguez M, Robles J and Llobet A 2002 Inorg. Chem. 41 6153; Rodríguez $\mathrm{M}$, Llobet $\mathrm{A}$ and Corbella M 2000 Polyhedron 19 2483, and references cited therein; Sangeetha N R and Pal S 2000 Polyhedron 191593

16. Brown S J, Tao X, Wark T A, Stephan D W and Mascharak P K 1988 Inorg. Chem. 271581

17. Brown S J, Tao X, Stephan D W and Mascharak P K 1986 Inorg. Chem. 253377 